The Bangladesh Veterinarian (2015) 32(2): 55 - 64

\title{
Topical application of silver-curcumin on wound healing in rabbits
}

\author{
R Islam, UK Rima1, MM Haq, MM Hossain, MM Rahman* and MAHNA Khan² \\ Department of Surgery and Obstetrics, Faculty of Veterinary Science, Bangladesh \\ Agricultural University, Mymensingh-2202, Bangladesh
}

\begin{abstract}
Curcumin, a natural product obtained from the rhizomes of Curcuma longa, is used traditionally in prevention of wound infection. To determine the effects of silver and curcumin combination on surgical wound healing, a study was conducted in rabbits. A total of 32 surgical wounds were created in 16 rabbits in four groups. Information was recorded from Day 0 to Day 42 postoperatively. Swelling area of wound, elevation of suture line from the skin surface, width of sutured area and contraction length were recorded weekly. Treatment with curcumin, $1 \%$ silver sulfadiazine (1\% SSD) and a mixture of the two resulted in swelling of $11.4 \pm 0.1 \mathrm{~mm}, 11.1 \pm 0.4 \mathrm{~mm}$ and $11.0 \pm 0.1 \mathrm{~mm}$, respectively. Swelling $(12.2 \pm 0.3 \mathrm{~mm})$ and elevation of sutured line was higher $(3.4 \pm 0.2$ $\mathrm{mm})$ in wounds of control group and lower $(2.3 \pm 0.1 \mathrm{~mm})$ in wounds treated with a mixture of curcumin and 1\% SSD. The scores of wound colonization were lowest $(0.8)$ in $1 \%$ SSD group followed by mixture of curcumin and 1\% SSD (1.0), curcumin (1.3) and tincture of benzoin (1.6) alone. Histopathologically reactive cells decreased markedly in wounds treated with combination of $1 \%$ SSD and curcumin at $\mathrm{D}_{3}$ with increased fibrous connective tissue. However, wounds treated with 1\% SSD showed fewer reactive cells than curcumin group. Proliferation of fibrous connective tissue was highest in the silver treated wound, which indicates good wound healing process. Overall, wound healing was improved by the topical application of $1 \%$ SSD alone. Curcumin had positive effects on wound healing process but less than 1\% SSD. These results indicate that $1 \%$ silver sulfadiazine is the best topical therapy for wound management in rabbits. (Bangl. vet. 2015. Vol. 32, No. 2, 55 - 64)
\end{abstract}

\section{Introduction}

Wounds are reported to be the most common surgical condition in animals. Healing of wounds is a complex biological event (Gillitzer et al., 2001) and extrinsic and intrinsic factors may result in complications (Hess et al., 2003). A wound may lead to serious consequences if not treated (Harpal and Kuldip, 1993; Mashhood et al., 2006). Typically, the steps in the wound repair process include inflammation, angiogenesis, development of granulation tissue, repair of connective and epithelial tissues, and ultimately remodelling (Midwood et al., 2004).

1Department of Medicine, Surgery and Obstetrics, Hajee Mohammad Danesh Science and Technology University, Dinajpur, Bangladesh

2 Department of Pathology, Faculty of Veterinary Science, Bangladesh Agricultural University,

Mymensingh-2202, Bangladesh

*Corresponding author:- E-mail: miznih@gmail.com 
Treatment of wounds is important to achieve the best functional and aesthetic results in a short time (Myers et al., 1980; Adams et al., 2003; Mamun, 2012). Topical antibacterial therapy may alter the wound environment by reduction of fibroplasia or promotion of epithelialization (Stashak, 1991; Mashhood et al., 2006). Silver nitrate, Nano crystalline silver, and some silver-containing dressings have anti-inflammatory effects and encourage neovascularization (Walker et al., 2007; Kontoes et al., 2010; Wilkinson et al., 2011).

Benefits of oral and topical use of curcumin (diferuloylmethane), a natural product obtained from the rhizomes of Curcuma longa, for the treatment of cutaneous wound has been reported (Sidhu et al., 1999). It has been reported that curcumin accelerates wound healing in cattle (Mamun, 2012). Curcumin improves re-epithelialization and migration of cells such as myofibroblasts, fibroblasts, and macrophages (Sidhu el al., 1999). Curcumin inhibits pain and inflammation by selectively inhibiting the arachidonic acid cascade (Gong et al., 2013). Curcumin acts as a scavenger of nitric oxide and inhibits cyclo-oxygenase (COX-2), a pro-inflammatory cytokines (Mamun, 2012). No research has been reported on open wound healing in rabbits using silver sulfadiazine and curcumin combination. The present study was designed to study the therapeutic effects of curcumin (Curcuma longa) and silver sulfadiazine on surgical wound in rabbits.

\section{Materials and Methods}

\section{Study location}

A series of studies were done on rabbits to find out the effect of silver and curcumin in healing of surgical wounds sutured with simple interrupted pattern using silk. The studies were conducted at the experimental shed of the Department of Medicine, Bangladesh Agricultural University, Mymensingh from January to May 2013.

\section{Experimental animals}

With the approval of the Department of Surgery and Obstetrics, Bangladesh Agricultural University, Mymensingh 16 apparently healthy rabbits were used. Body weight of the animals ranged from 1.8 to $2.0 \mathrm{Kg}$. The animals were kept under standard laboratory conditions and veterinary supervision with water and food ad libitum. Before the study the rabbits were kept in quarantine for three weeks.

\section{Preparation of 1\% silver cream and turmeric paste}

Silver cream was prepared with $1 \%$ silver sulfadiazine (SSD) and $99 \%$ paraben

(Burnsil ${ }^{\odot}$, Beximco Pharmaceuticals, Bangladesh). Fresh herbal pastes were prepared from turmeric root (Curcuma longa). The fresh turmeric roots were purchased from KR Shopping centre, Bangladesh Agricultural University campus, Mymensingh. The roots were cleaned with water. These were ground in a mortar to prepare cream. A combination was made by mixing (1:1) $1 \%$ SSD cream and turmeric paste. 


\section{Experimental design}

A total of 32 surgical wounds were made on the skin of 16 rabbits with two in each. Rabbits were divided into four groups with four animals in each group (Table 1).

Group-T: Fresh turmeric paste was applied locally to surgical wounds daily. These animals were maintained so as to avoid interference with granulation tissue formation.

Group-S: Silver sulfadiazine 1\% cream was applied to surgical wounds in each animal daily. The treatment schedule was as in Group-T.

Group-ST: A mixture of silver sulfadiazine 1\% cream and turmeric was applied locally daily to surgical wounds.

Group-C: This group was kept as control. In this group tincture of benzoin was applied in surgical wounds in rabbits.

Table 1. Treatment of surgical wounds with topical application of silver and turmeric in rabbits

\begin{tabular}{c|c|c|c|c}
\hline Group & Materials for treatment & Form of materials & No. of animals & No. of wounds \\
\hline T & Turmeric & Paste & 4 & 8 \\
S & 1\% SSD & Cream & 4 & 8 \\
ST & Turmeric and 1\% SSD & Paste & 4 & 8 \\
C & Control & Solution & 4 & 8 \\
& (Tincture of benzoin) & & & \\
\hline
\end{tabular}

$\mathrm{SSD}=$ silver sulfadiazine

All wounds were closed with simple interrupted suture using silk thread. Follow-up information was obtained from day of surgical operation up to Day 42 after surgery. Swellings, elevation of sutured line from the skin surface, width of sutured area were recorded. Elevation of sutured line was recorded up to 7 days of surgery. Width of sutured area was measured at Day $0\left(\mathrm{D}_{0}\right)$, Day $3\left(\mathrm{D}_{3}\right)$, Day $7\left(\mathrm{D}_{7}\right)$, Day $14\left(\mathrm{D}_{14}\right)$, Day 21 $\left(D_{21}\right)$ to determine wound contraction length. Tissue samples were collected from all treatment groups at $\mathrm{D}_{1}, \mathrm{D}_{3}$ and $\mathrm{D}_{7}$ for histopathological study.

\section{Anaesthesia}

The rabbits were anaesthetized with single intramuscular injections of $6 \mathrm{mg} / \mathrm{kg}$ xylazine hydrochloride (Xylaxin ${ }^{\odot}, 23.2 \mathrm{mg} / \mathrm{mL}$, Indian Immunological Ltd., India) and $40 \mathrm{mg} / \mathrm{kg}$ ketamine hydrochloride (G-Ketamine ${ }^{\odot}$, Gonosasthya, Bangladesh, 50 $\mathrm{mg} / \mathrm{mL}$ ketamine hydrochloride USP).

\section{Surgical wound}

The thigh region of the rabbits was shaved and cleaned with $10 \%$ Povidone Iodine solution. Surgical wound of $1 \mathrm{~cm}$ length and $0.5 \mathrm{~cm}$ depth was made. Exudates were 
removed by dry gauze. Wound was closed with simple interrupted suture using silk thread. All sutures were placed $8 \mathrm{~mm}$ apart. Distance between suturing needle placement and border of cutting edge was $5 \mathrm{~mm}$.

\section{Observation of morphological changes}

Slide calipers was used to measure swelling area ( $\mathrm{mm})$, elevation of suture line $(\mathrm{mm})$, wound contraction and width of sutured area of wound $(\mathrm{mm})$. Swelling was observed up to three days after operation because swelling started decreasing gradually from Day $3\left(\mathrm{D}_{3}\right)$. Elevation of sutured line was recorded until 7 days after surgery. Width of sutured area was measured from the day of surgical intervention Day $0\left(\mathrm{D}_{0}\right)$, Day 3 $\left(\mathrm{D}_{3}\right)$, Day $7\left(\mathrm{D}_{7}\right)$, Day $14\left(\mathrm{D}_{14}\right)$, Day $21\left(\mathrm{D}_{21}\right)$.

\section{Assessment of wound colonization}

Wound colonization was assessed according to exudation, purulent efflux, efflux odour, erythema and oedema. A score range from 0 and 3 was presented here:

$0:$ No finding of colonization

1 : Mild exudation and odour

2 : Erythema, moderate purulent efflux, exudation and odour

3 : Severe exudation, purulent efflux, odour, oedema and erythema.

Each assessment was performed by the same blinded worker who was unaware of the scores of rabbits determined before and during the treatment.

\section{Assessment of wound healing}

This study was continued for six weeks after the formation of surgical wound. Each wound was clinically observed and digital photos were taken with a camera every three days during the following six weeks. Wounds were considered to have healed when visible epithelium covered the wound and cicatrisation and pigmentation was found. The days to healing were recorded for all the animals and the mean time was calculated for each group.

\section{Histopathological assessment}

Biopsies $(1.5 \mathrm{~cm} \times 1 \mathrm{~cm})$ were collected from the wound areas of each animal on the $1^{\text {st }}$, $3^{\text {rd }}$ and $7^{\text {th }}$ days after wounding using standard surgical procedure. The wound tissue contained dermis and epidermis. The samples were fixed in $10 \%$ buffered neutral formalin solution more than seven days for histopathology. Histopathological slides were prepared and the whole procedure was performed by the Department of Pathology, Bangladesh Agricultural University, Mymensingh.

\section{Statistical analysis}

The data obtained in the present study were analysed with SPSS statistics 17.0 software. Probability $\mathrm{P}<0.05$ was considered statistically significant. 


\section{Results and Discussion}

At the beginning of the study, all the surgical wounds were similar. At the end of six weeks, no unhealed wounds were present.

\section{Morphological changes}

Swelling of the wound edges was observed in all four groups (Table 2). Treatment with curcumin (group T), silver (group S) and mixture of both (group ST) resulted in the swelling area $11.4 \pm 0.1 \mathrm{~mm}, 11.1 \pm 0.4 \mathrm{~mm}$ and $11.0 \pm 0.1 \mathrm{~mm}$ respectively; there was no significant difference (Table 2$)$. The swelling $(12.2 \pm 0.3 \mathrm{~mm})$ was significantly $(\mathrm{P}<0.05)$ higher in group $\mathrm{C}$ (Control group). Elevation of sutured line was higher $(3.4$ $\pm 0.2 \mathrm{~mm}$ ) in group $C$ and lower $(2.2 \pm 0.1 \mathrm{~mm})$ in group ST (Table 3). Higher swelled area and elevated suture line indicate more inflammation in control group. The contraction length varied insignificantly (P>.05) among the groups (Table 2).

Table 2. The effect of $1 \%$ silver sulfadiazine-curcumin on wound healing in rabbits

\begin{tabular}{l|c|c|c}
\hline \multicolumn{1}{c|}{ Groups } & $\begin{array}{c}\text { Swelling of suturing area } \\
(\mathrm{mm})\end{array}$ & $\begin{array}{c}\text { Elevation of } \\
\text { sutured line }(\mathrm{mm})\end{array}$ & $\begin{array}{c}\text { Average contraction } \\
\text { length (mm/week) }\end{array}$ \\
\hline Group S & $11.1 \pm 0.1^{\mathrm{a}}$ & $2.3 \pm 0.11^{\mathrm{a}}$ & $1.5 \pm 0.2$ \\
Group T & $11.4 \pm 0.1^{\mathrm{a}}$ & $2.4 \pm 0.21^{\mathrm{a}}$ & $1.6 \pm 0.2$ \\
Group ST & $11.0 \pm 0.1^{\mathrm{a}}$ & $2.2 \pm 0.10^{\mathrm{a}}$ & $1.4 \pm 0.1$ \\
Group C & $12.2 \pm 0.3^{\mathrm{b}}$ & $3.4 \pm 0.23^{\mathrm{b}}$ & $1.8 \pm 0.1$ \\
\hline
\end{tabular}

$a, b$ indicate significant $(\mathrm{P}<0.05)$ difference in groups; Mean \pm SEM

\section{Wound colonization}

The scores of wound colonization were lowest in group S (0.8) followed by group ST (1.0), $\mathrm{T}$ (1.3) and C (1.6). This reveals that odour and exudation from wounds of silver-treated group were minimum due to least microbial changes. These differences were significant only at weeks 1, 2 and $3(\mathrm{P}<0.05)($ Graph 1$)$.

\section{Days to healing}

No significant differences $(P>0.05)$ on the healing time were observed among the groups (Table 4). The mean days to complete healing ranged from 30 days for group $S$ to 38 days for group $C$ with a mean for all groups of 34 days (Graph 2).

\section{Histopathological changes}

Infiltration of reactive cells including neutrophils, macrophages and lymphocytes were present in all samples, which indicated inflammation. Additionally, tissue debris and haemorrhage were present and blood vessels were congested in the wounds of control group (Group C) at $\mathrm{D}_{1}$. Reactive cells decreased markedly in wounds treated with combination of $1 \%$ silver sulfadiazine and curcumin at $\mathrm{D}_{3}$. Fibrous connective tissue was observed on this sample at $\mathrm{D}_{3}$ (Fig. 2d). Wounds treated with $1 \%$ SSD showed fewer reactive cells than those of curcumin group collected at $\mathrm{D}_{3}$ (Fig. $2 \mathrm{~b}$ and 2c). Notably, the proliferation of fibrous connective tissue was the highest in the silver- 
treated wound (Fig. 2c). Continuous formation of keratin layer was observed in group $\mathrm{S}$ (Fig. 3a) at $\mathrm{D}_{7}$. In case of group ST, healing was progressed (Fig. 3c) at $\mathrm{D}_{7}$. A comparatively thick keratinized layer was in group T (Fig. 3b). However, the edges of the wound sample of control group at $\mathrm{D}_{7}$ did not come in apposition although; keratin layer was formed along the edges of the incised tissue (Fig. 3d). It may be due to lack of joining the two edges and consequently retarded healing of the wound in this group.

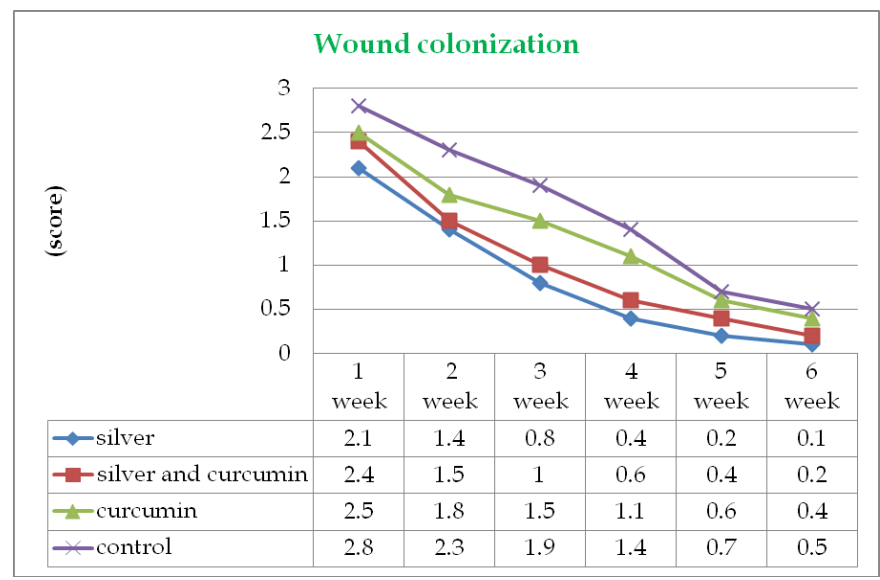

Graph 1. Progress of colonized wounds of four groups in six consecutive weeks

Table 3. Time required for healing of wounds treated with silver, curcumin, a combination of silver and curcumin, and tincture of benzoin

\begin{tabular}{l|c|c|c|c}
\hline \multirow{2}{*}{$\begin{array}{c}\text { No. of } \\
\text { animals }\end{array}$} & \multicolumn{4}{c}{ Healing time (days) } \\
\cline { 2 - 5 } & Silver & Silver + Curcumin & Curcumin & $\begin{array}{c}\text { Tincture of } \\
\text { benzoin }\end{array}$ \\
\hline 1. & 29 & 42 & 42 & 38 \\
2. & 32 & 32 & 38 & 36 \\
3. & 28 & 28 & 32 & 38 \\
4. & 31 & 30 & 35 & 40 \\
Average & $30.0 \pm 0.1$ & $33.0 \pm 0.1$ & $36.7 \pm 0.2$ & $38.0 \pm 0.2$ \\
\hline
\end{tabular}

$\mathrm{P}>0.05$ comparing the groups

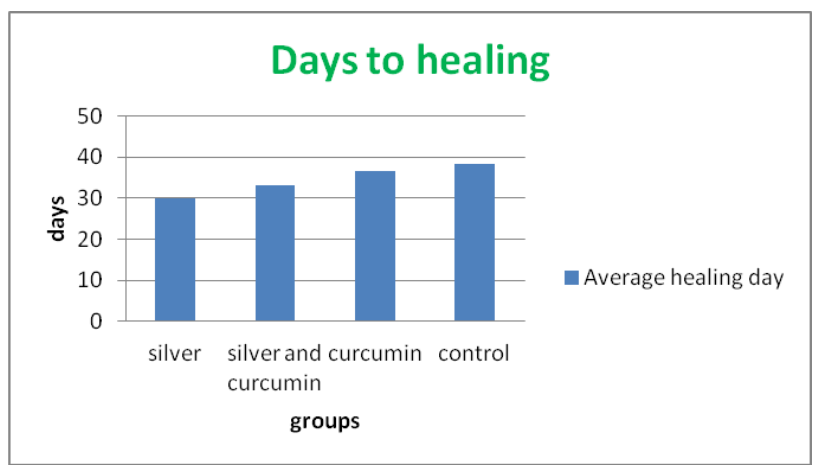

Graph 2. Mean days to wound healing 

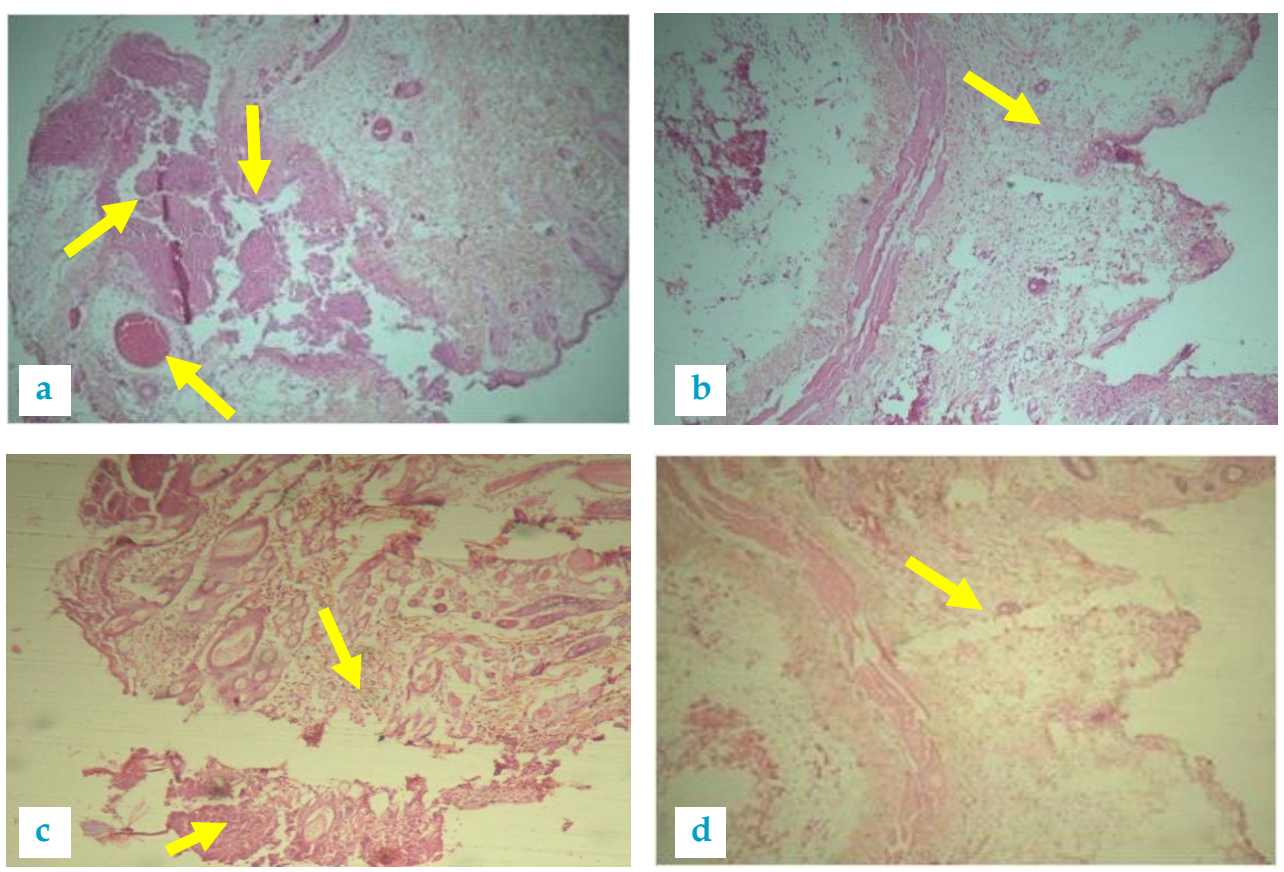

Fig. 1. Presenceof reactivecells (arrows) beneaththe keratinizedtissues of epidermisof woundsof controlgroup (a), groupS (b), group T (c) and groupST (d) at $\mathrm{D}_{1}$ after treatment.Congestec blood vessel is seen (dark circle) in control group (a).
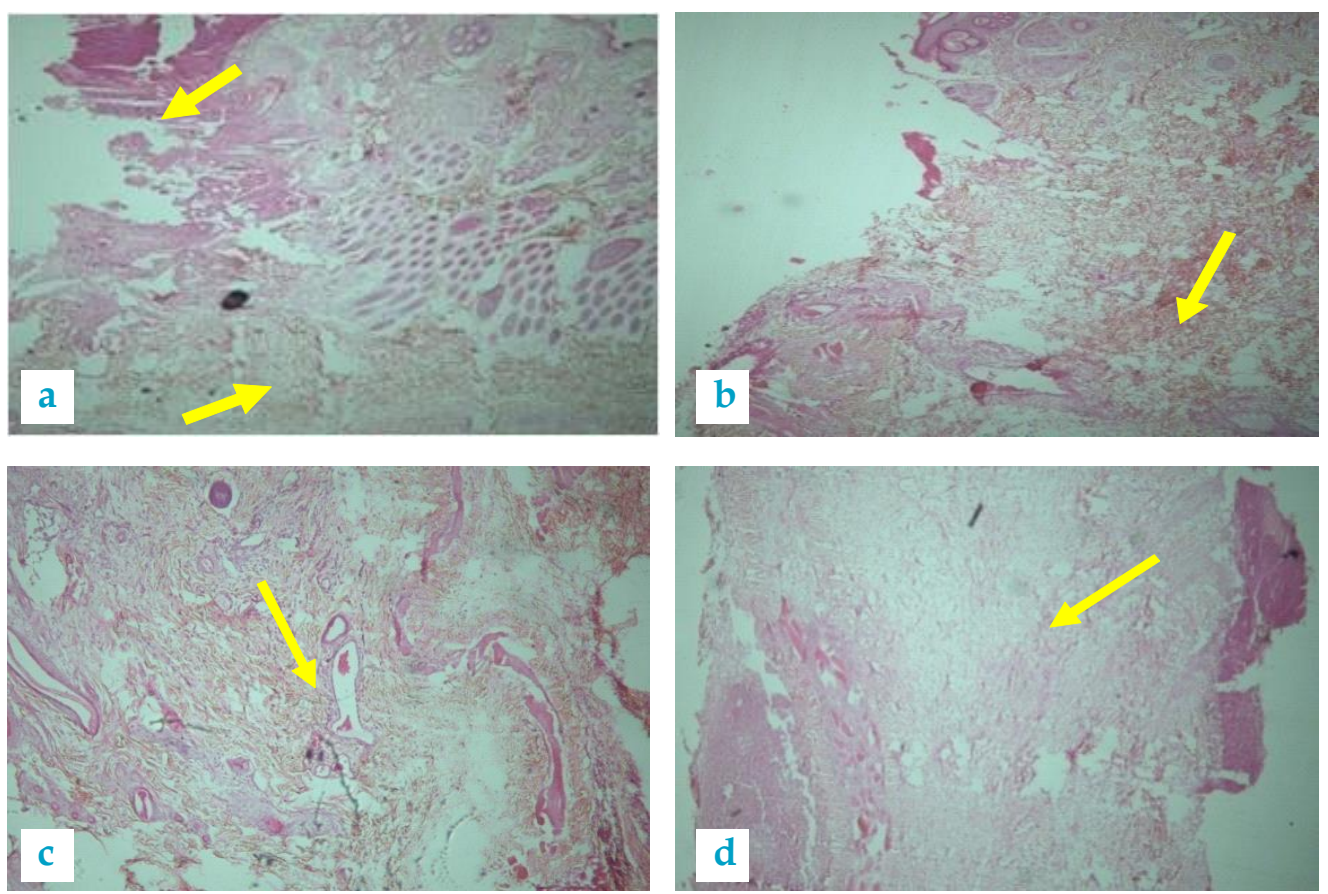

Fig. 2. Presenceof reactivecells(darkcolor)and newlyformedfibroustissue(whitisharea)in wounds of group C (a), group T (b) group S (c) and group ST ( $\mathrm{d}_{3}$ after treatment. 

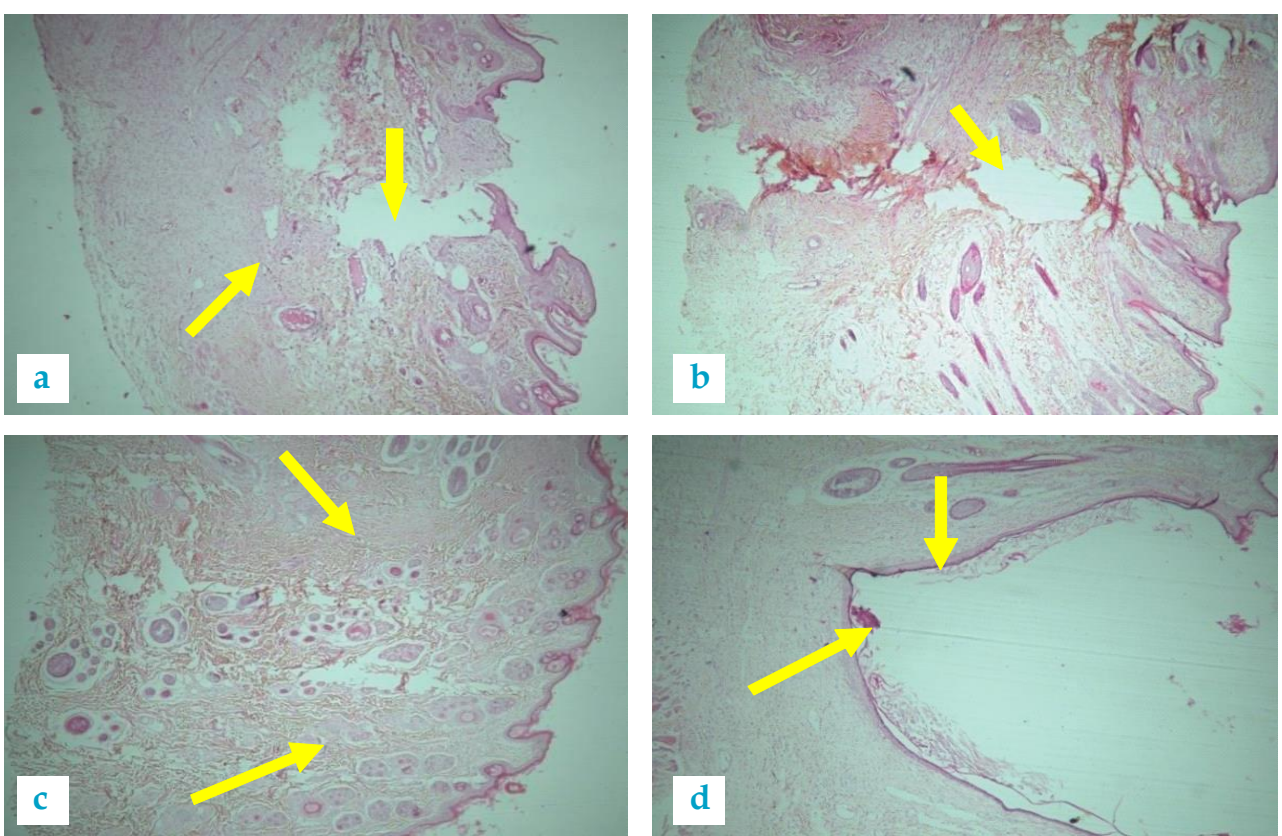

Fig. 3. Histopathologicadhangesin woundsof silver(a), curcumin(b) and mixtureof both (c) groups at D7. Progressof healingalongwithnewlyformedconnectivetissue(c) in ST (mixturegroup), continuationf Keratinlayerformationin curcumin(a) and silver(c) groupsarementionedwith arrows. Healing was retarded in control group (d).

Cicatrisation is an intricate process in which the skin repairs itself after injury (Nguyen et al., 2009). The application of topical medications is one means of keeping a wound free from contamination. These preparations allow high local antimicrobial efficacy while avoiding systemic toxicity and are most effective in the earlier stages of healing prior to a solid granulation bed (Brandt et al., 2012). The increased swelling and width of sutured area following treatments were noted up to Day $3\left(\mathrm{D}_{3}\right)$ postoperatively. The record of the width of wound area at Day $7\left(D_{7}\right)$ and Day $14\left(D_{14}\right)$ postoperatively has been done to understand wound contraction process morphologically. There was no significant variation in wounds of all groups in term of diminishing contraction length per week. This result supports the hypothesis that wound contraction depends on the myofibroblast located at the periphery of the wound, its connection to components of the extra cellular matrix and myofibroblast proliferation (Rohrich, 1990). Among four groups, higher swelled area and elevation of suture line were observed in wounds of control group (treated with tincture of benzoin) in comparison to that of other three groups. This result hypothesizes that tincture of benzoin cause marked tissue reaction in wounds.

In this study $1 \%$ SSD cream produced comparatively better results in wound healing as a topical medication. It produced wound healing in 30 days, 33 days treated with mixture of $1 \%$ SSD and curcumin, 36 days with curcumin and 38 days in control group. Additionally, the scores of wound colonization were the lowest $\left(2.2\right.$ in $1^{\text {st }}$ 
week) in silver treated animals (group S). Silver sulfadiazine increases the rate of reepithelialization in acute and chronic wounds and had good effects in wound healing (Kontoes et al., 2010; Choi et al., 2013). It may be suggested that, 1\% silver sulfadiazine may be used as an effective topical medication for treating wounds in rabbits.

In this study, no negative effect from either 1\% SSD or curcumin paste was observed. It is believed that either the turmeric or the silver can be used clinically in wound healing. However, in silver-treated wounds, there was early subsidence of inflammation, better control of infection and quicker wound healing compared to the other three groups. It is recommended that $1 \%$ SSD may be a practical choice for wound care. It also relieves pain, makes the wound sterile and is available in the local markets. Further investigation is necessary to determine the relative safety of these products on the healing wound. Once that is done, the relative value of the products can be determined.

\section{Conclusions}

Wound care is improved and simplified by the topical use of $1 \%$ silver sulfadiazine.

\section{References}

Adams B, Jamshaid AM, David A, Wrone MD, Alam MM 2003: Techniques for cutaneous sutured closures, variants and indications. Journal of Veterinary Surgery 30 311-314.

Brandt O, Mildner M, Egger AE, Groessl M, Rix U, Posch M, Keppler BK, Strupp C, Mueller B, Stingl G 2012: Nanoscalic silver possesses broad-spectrum antimicrobial activities and exhibits fewer toxicological side effects than silver sulfadiazine. Nanomedicine 8 478-488.

Choi JB, Park JS, Khil MS, Gwon HJ, Lim YM, Jeong SI, Shin YM, Nho YC 2013: Characterization and antimicrobial property of poly (acrylic Acid) nanogel containing silver particle prepared by electron beam. International Journal of Molecular Science $\mathbf{1 4}$ 11011-11023.

Gong C, Wu Q, Wang Y, Zhang D, Luo F, Zhao X, Wei Y, Qian Z 2013: A biodegradable hydrogel system containing curcumin encapsulated in micelles for cutaneous wound healing. Biomaterials 34 6377-6387.

Gillitzer R, Goebeler M 2001: Chemokines in cutaneous wound healing. Journal of Leukocyte Biology 69 513-521.

Harpal S, Kuldip S 1993: Wound healing and tissue repair. In: Ruminant Surgery. $1^{\text {st }}$ edn. Edited by RAS Tyagi, J Singh. CDS Publishers and Distributors, Delhi, India. pp. 58-71.

Hess CT, Kirsner RS 2003: Orchestrating wound healing: Assessing and preparing the wound bed. Advanced Skin and Wound Care 16 246-257. 
Kontoes PP, Vrettou CP, Loupatatzi AN, Marayiannis KV, Foukas PG, Vlachos SP 2010: Wound healing after laser skin resurfacing: the effect of a silver sulfadiazinehyaluronic acid-containing cream under an occlusive dressing. Journal of Cosmetic and Laser Therapy 12 10-13.

Mamun MAA 2012: Comparative effect of turmeric (Curcuma longa) and durba (Cynodondactylon) on the healing of surgical wounds in cattle (Bos indicus). MS Thesis. Department of Surgery and Obstetrics, Bangladesh Agricultural University, Mymensingh-2202, pp. 37-41.

Mashhood AA, Khan TA, Sami AN 2006: Honey compared with 1\% silver sulfadiazine cream in the treatment of superficial and partial thickness burns. Journal of Pakistan Association of Dermatology 16 14-19.

Midwood KS, Williams LV, Schwarzbauer JE 2004: Tissue repair and the dynamics of the extracellular matrix. International Journal of Biochemistry and Cell Biology 36 1031-1037.

Myers KA, Marshal RD, Friedin J 1980: Principles of Pathology in Surgery, $1^{\text {st }}$ edn. Blackwell Scientific Publications: London. pp. 58-82

Nguyen, DT, Orgill DP, Murphy GF 2009: The Pathophysiologic Basis for Wound Healing and Cutaneous Regeneration. In: Biomaterials For Treating Skin Loss. Woodhead Publishing (UK/Europe) \& CRC Press (US), Cambridge/Boca Raton. pp. 25-57.

Rohrich RJ 1990: Wound healing and closure, abnormal scars, envenomation and extravasation injuries. In: Plastic Surgery. Edited by JG McCarthy. WB Saunders, Philadelphia, USA. pp. 2-17.

Sidhu GS, Mani H, Gaddipati JP, Singh AK, Seth P, Banaudha KK, Patnaik GK, Maheshwari RK 1999: Curcumin enhances wound healing in streptozotocin induced diabetic rats and genetically diabetic mice. Wound Repair and Regeneration 7 362-374.

Stashak TS 1991: Principles of Wound Healing. In: Equine Wound Management, Edited by Malern PA, Published by Lea \& Febiger. pp. 11.

Walker M, Bowler PG, Cochrane CA 2007: In vitro studies to show sequestration of matrix metalloproteinases by silver-containing wound care products. Ostomy Wound Management 53 18-25.

Wilkinson LJ, White RJ, Chipman JK 2011: Silver and nanoparticles of silver in wound dressings: a review of efficacy and safety. Journal of Wound Care 20 543-549. 